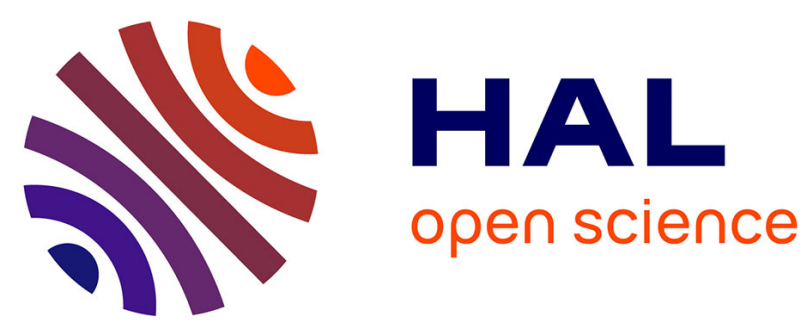

\title{
Evidence for Targeting Thioredoxin Reductases with Ferrocenyl Quinone Methides. A Possible Molecular Basis for the Antiproliferative Effect of Hydroxyferrocifens on Cancer Cells
}

Anna Citta, Alessandra Folda, Alberto Bindoli, Pascal Pigeon, Siden Top, Anne Vessières, Michèle Salmain, Gérard Jaouen, Maria Pia Rigobello

\section{To cite this version:}

Anna Citta, Alessandra Folda, Alberto Bindoli, Pascal Pigeon, Siden Top, et al.. Evidence for Targeting Thioredoxin Reductases with Ferrocenyl Quinone Methides. A Possible Molecular Basis for the Antiproliferative Effect of Hydroxyferrocifens on Cancer Cells. Journal of Medicinal Chemistry, 2014, 57 (21), pp.8849-8859. 10.1021/jm5013165 . hal-01230376

\section{HAL Id: hal-01230376 https://hal.science/hal-01230376}

Submitted on 2 May 2018

HAL is a multi-disciplinary open access archive for the deposit and dissemination of scientific research documents, whether they are published or not. The documents may come from teaching and research institutions in France or abroad, or from public or private research centers.
L'archive ouverte pluridisciplinaire HAL, est destinée au dépôt et à la diffusion de documents scientifiques de niveau recherche, publiés ou non, émanant des établissements d'enseignement et de recherche français ou étrangers, des laboratoires publics ou privés. 


\section{Evidence for Targeting Thioredoxin Reductases with Ferrocenyl Quinone Methides. A Possible Molecular Basis for the Antiproliferative Eff ect of Hydroxyferrocifens on Cancer Cells}

Anna Citta, ${ }^{1}$ Alessandra Folda, ${ }^{1}$ Alberto Bindoli, ${ }^{2}$ Pascal Pigeon,,${ }^{3,4}$ Siden Top, ${ }^{3,4}$ Anne Vessieres, ${ }^{3,4}$ Michele Salmain, ${ }^{3,4}$ Gerard Jaouen, ${ }^{, 3,4,5}$ and Maria Pia Rigobello*,

${ }^{1}$ Dipartimento di Scienze Biomediche, Università di Padova, via Ugo Bassi 58/b, 35131 Padova, Italy

${ }^{2}$ Istituto di Neuroscienze, CNR, Viale G. Colombo 3, 35121 Padova, Italy

${ }^{3}$ Sorbonne Universites, UPMC Univ Paris 06, UMR 8232, IPCM, F-75005 Paris, France

${ }^{4}$ CNRS, UMR 8232, IPCM, F-75005 Paris, France

${ }^{5}$ PSL, Chimie ParisTech, 11 rue Pierre et Marie Curie, F-75005 Paris, France

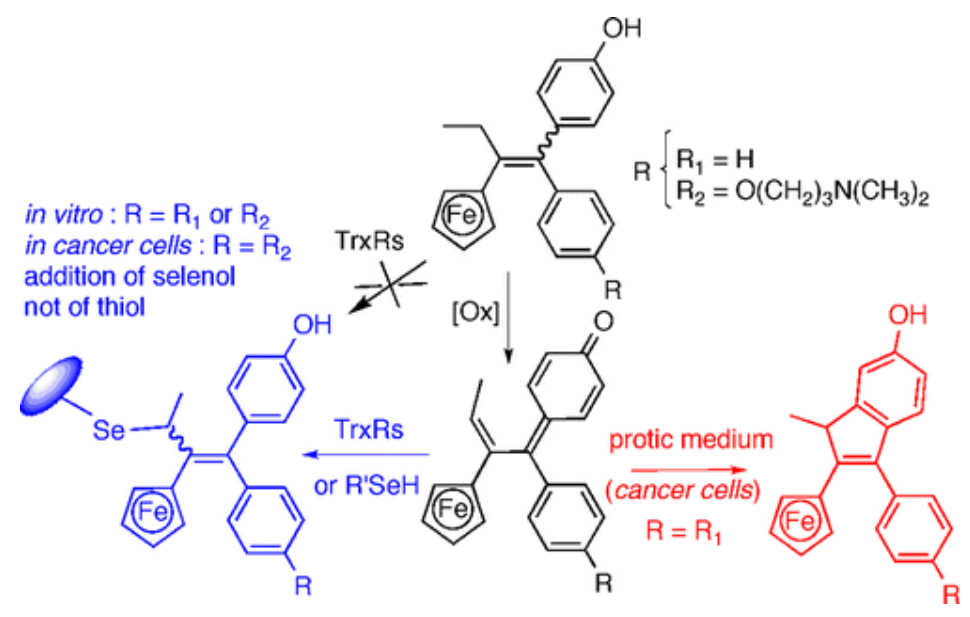

ABSTRACT: Many anticancer compounds are strong inhibitors of thioredoxin reductases (TrxRs), selenoenzymes involved in cellular redox regulation. This study examined the eff ect of two hydroxyferrocifens $(\mathbf{1}, \mathrm{FcOH} ; 2$, FcOHTAM) and of their corresponding quinone methides (QMs), 1-QM, and 2-QM, on these enzymes. In vitro, both QMs were more 
potent TrxR inhibitors $\left(\mathrm{IC}_{50} \approx 2.5 \mu \mathrm{M}\right)$ than the hydroxyferrocifens $\left(\mathrm{IC}_{50} \approx 15 \mu \mathrm{M}\right)$. This inhibition was due to a Michael addition of the penultimate selenocysteine residue of TrxRs to the QMs. In Jurkat cancer cells, both 2 and 2-QM inhibited TrxRs in the same proportion, leading to accumulation of oxidized forms of thioredoxin, while $\mathbf{1}$ and 1-QM were scarcely eff ective. This difference of behavior was ascribed to the competitive conversion of 1-QM to an inactive indene in protic medium. This set of experiments confirms for the first time the role played by ferrocenyl quinone methides on several biological targets and gives a molecular basis for these eff ects. It also highlights differences in the mechanisms of action of $\mathbf{1}$ and $\mathbf{2}$ in cancer cells.

\section{INTRODUCTION}

Triple negative breast cancers, melanomas, glioblastomas, pancreatic cancers, ovarian, and nonsmall-cell lung cancers are some of the cancers associated with the worst outcomes thanks to their ability to resist most of the standard therapies. The health challenge represented by these cancers can only be met by innovative medical approaches that combine ground-breaking chemistry with novel biology and the latest tools of medical intervention. All these cancers share the characteristics of intrinsic resistance to pro-apoptotic stimuli, which limits the eff ectiveness of the available chemotherapies. ${ }^{1}$

In the search for new therapeutic strategies, a new medicinal chemistry based on the unique behavior of organometallic complexes of transition metals may provide a

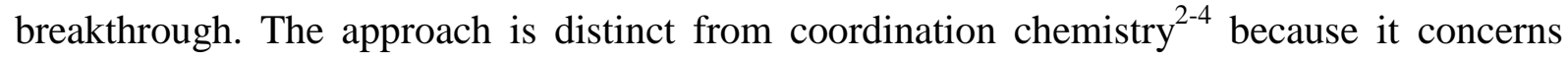
organometallics with a direct metal-carbon covalent bond, often associated with a low degree of oxidation. The advent of organometallic frameworks designed with precise biological end points in mind was delayed for some time by organometallic chemists' primary focus on catalysis, which for some years had the eff ect of relegating other aspects of the field to obscurity. ${ }^{5}$ This situation changed with the arrival of bioorganometallics. ${ }^{6,7}$ It is now clear that an innovative organometallic medicinal chemistry ${ }^{8,9}$ is supported by the distinctive properties of organometallic complexes, for example, the three-dimensional space-filling capability demonstrated by Dör and Meggers for kinase and other enzyme inhibitors. ${ }^{10}$ Alternatively, some organometallic complexes inhibit target proteins by metal coordination to their active site. ${ }^{11-13}$ In this context, the potential interest of $N$-heterocyclic carbene (NHC) 
complexes of $\mathrm{Au}(\mathrm{I})$ and $\mathrm{Ru}(\mathrm{II})$ as anticancer drugs has been evaluated. ${ }^{14-17} \mathrm{NHC}$ ligands stabilize metal ions against precipitation into aggregates under physiological conditions and at the same time can serve to deliver bioactive metal ions to the cellular targets. These species have mechanisms of action diff erent from that of cisplatin ${ }^{2}$ because redox proteins such as thioredoxin reductase (TrxR) can be considered as key targets.

Another strategy to overcome cancer cell resistance with new types of organometallic prodrugs is to use non-noble metals and generate active metabolites in the vicinity of redox targets. Among the usable organometallic complexes, the iron complexes occupy a privileged position owing to the abundance of this metal in the body and the particular nature of ferrocene, which is a compact and stable aromatic metallocene with redox properties and a bioisostere of benzene. ${ }^{8}$

For example, substitution of a phenyl ring by a ferrocenyl unit in OHTAM, the active metabolite of tamoxifen, the drug classically used to treat hormone dependent breast cancer leads to FcOHTAM (Chart 1), which showed a strong cytotoxic eff ect on both estrogen receptor positive and negative breast cancer cell lines (MCF-7 and MDA-MB-231, respectively). ${ }^{18-20}$

\section{Chart 1. Chemical Structures of the Ferrocenyl Derivatives under Study}

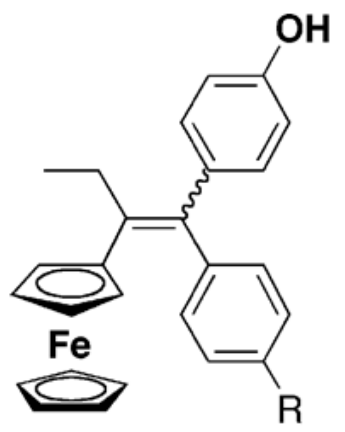

1: $\mathrm{FcOH}(E+Z), \mathrm{R}=\mathrm{H}$

2: $\mathrm{FcOHTAM}(E+Z), \mathrm{R}=\mathrm{O}\left(\mathrm{CH}_{2}\right)_{3} \mathrm{~N}\left(\mathrm{CH}_{3}\right)_{2}$

3: $\mathrm{FcdiOH}, \mathrm{R}=\mathrm{OH}$

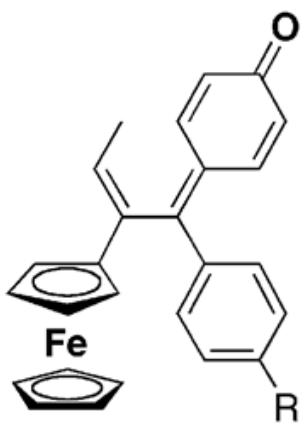

1-QM : $\mathrm{R}=\mathrm{H}$

2-QM : $\mathrm{R}=\mathrm{O}\left(\mathrm{CH}_{2}\right)_{3} \mathrm{~N}\left(\mathrm{CH}_{3}\right)_{2}$

3-QM : $\mathrm{R}=\mathrm{OH}$

Indeed an $\mathrm{IC}_{50}$ of $0.5 \mu \mathrm{M}$ was found for the lipophilic complexes 2 , the corresponding diphenol analogue $\mathbf{3}$, and $1.1 \mu \mathrm{M}$ for the ferrocenyl monophenol compound $\mathbf{1}$ on MDA-MB-231 cells. ${ }^{21-23}$ Compound 3 and other ferrocifens were active against a large panel of cancer cell lines ${ }^{24}$ but not on healthy cells (astrocytes, melanocytes). ${ }^{25,26}$ The eff ectiveness 
of $\mathbf{2}$ and $\mathbf{3}$ delivered via lipid nanocapsules (LNC) has been studied in vivo on 9L-glioma models $^{26,27}$ and on xenografted MDA-MB-231 cells. ${ }^{28}$ A significant slowing of tumor progression was observed, demonstrating the antiproliferative activity of these compounds in vivo.

1, 2, and 3 can undergo chemical oxidation to give the quinone methides (QM) as products of the initial oxidation of the $\mathrm{Fe}$ (II) of ferrocenyl to the $\mathrm{Fe}$ (III) of ferricinium. ${ }^{29}$ Electrochemical experiments have provided elucidation of the oxidation pathway leading to the quinone methide, which occurs at biologically relevant potentials. ${ }^{30}$ It has been speculated that the cytotoxicity of 1 and some other ferrociphenols may arise at least partly from the electrophilic character of the quinone methide metabolites. ${ }^{31}$

Two major systems, namely the thioredoxin (Trx) and glutathione (GSH) systems, are involved in the control of cellular thiol redox balance. The first system depends on thioredoxin reductase (TrxR) which is reduced by NADPH and in turn maintains Trx in the reduced form. ${ }^{32,33}$ Among other functions, Trx acts as an electron donor for the family of peroxiredoxins that catalyze the reduction of $\mathrm{H}_{2} \mathrm{O}_{2}$ to water. ${ }^{34}$ TrxRs are large homodimeric flavoproteins, and two isoforms, a cytosolic (TrxR1) and a mitochondrial (TrxR2) form, have been identified. ${ }^{35,36}$ TrxRs possess an N-terminal redox center characterized by a dithiol motif (Cys-XXXX-Cys) and a C-terminal active site with a Cys-Sec motif (Sec = selenocysteine). The $\mathrm{Sec}$ residue is characterized by a low $\mathrm{p} K_{\mathrm{a}}(5.24$ for the selenol/selenate couple compared to 8.25 for the thiol/thiolate couple), resulting in an enhanced nucleophilic character. ${ }^{37,38}$ Thioredoxin reductase is considered an attractive target for development of anticancer agents as it is frequently overexpressed in cancer cells. ${ }^{39-41}$ Some metal complexes inhibit TrxR at the nanomolar to submicromolar level mostly by metal coordination, ${ }^{42-44}$ while electrophilic organic compounds inhibit TrxR at the micro/submicromolar level. ${ }^{45-50}$ Both classes of inhibitors target TrxR via an (ir)reversible reaction with the Cys-Sec motif at the C-terminus.

The second system is based on glutathione, maintained in a reduced state by glutathione reductase (GR), which is in turn reduced by NADPH. ${ }^{51,52}$ Reduced glutathione acts as a substrate of glutathione peroxidase (GPx), another selenoenzyme able to decompose hydrogen peroxide to water, ${ }^{53}$ thereby contributing, together with peroxiredoxins, to the maintenance of cell redox balance. 
In the present study, the eff ect of $\mathbf{1}$ and $\mathbf{2}$ and their respective quinone methides (1-QM, 2QM) on the activity of the isolated selenoenzymes TrxR and GPx and the homologous enzyme GR as well as the reactivity of the QMs on organic models was investigated and compared. The eff ects of these compounds on molecules involved in cellular redox homeostasis was further studied on Jurkat cancer cells in order to shed light on the molecular mechanism of action of these compounds that may be responsible for cancer cell growth inhibition.

\section{RESULTS}

Synthesis of Quinone Methides (QMs). QMs derived from 1, 2, and 3 were synthesized by chemical oxidation in acetonitrile or acetone with freshly prepared $\operatorname{Ag}_{2} \mathrm{O}$ following an improved protocol, allowing the compounds to be obtained in the solid form (Scheme 1). 2D NMR analysis showed that only the E isomers were obtained. ${ }^{29}$

\section{Scheme 1. Synthesis of the Quinone Methides}

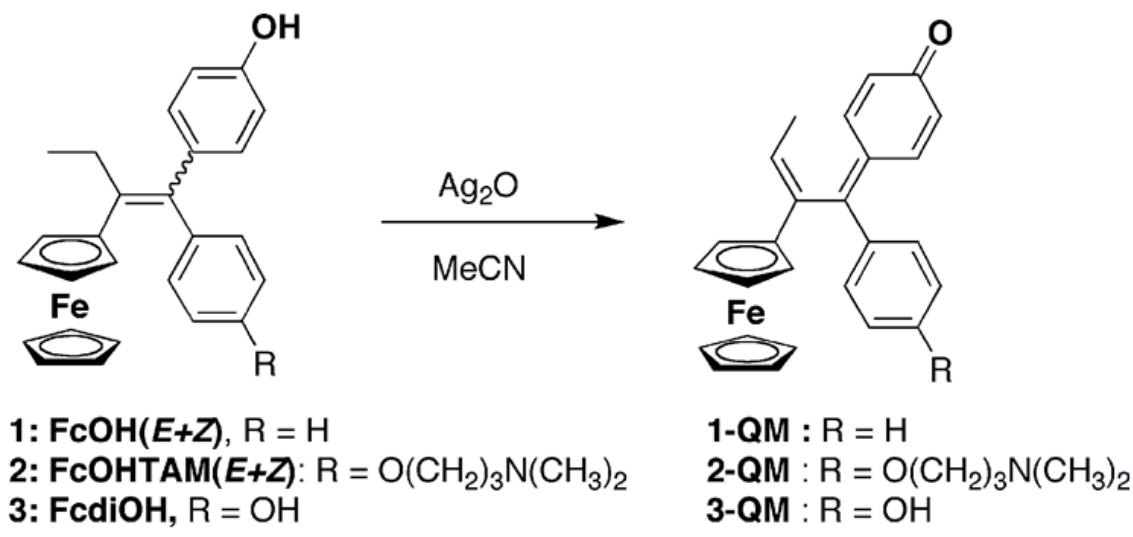

The QM of $3(3-Q M)$ proved to be quite unstable because it started to decompose before oxidation was complete. This is due to the presence of two oxidizable phenol groups on the molecule, possibly leading to uncontrollable overoxidation. The two other QMs showed reasonable stability, at least 4 weeks in the solid state when kept at $-20{ }^{\circ} \mathrm{C}$, and were thus chosen for this study. However, their stability in solution was limited (see below). Thus, although in vitro biochemical studies can be performed on both isolated enzymes and in 
cancer cells (Jurkat cell line) with 1-QM and 2-QM, $1 \mathrm{mM}$ stock solutions have to be freshly prepared for each set of experiments.
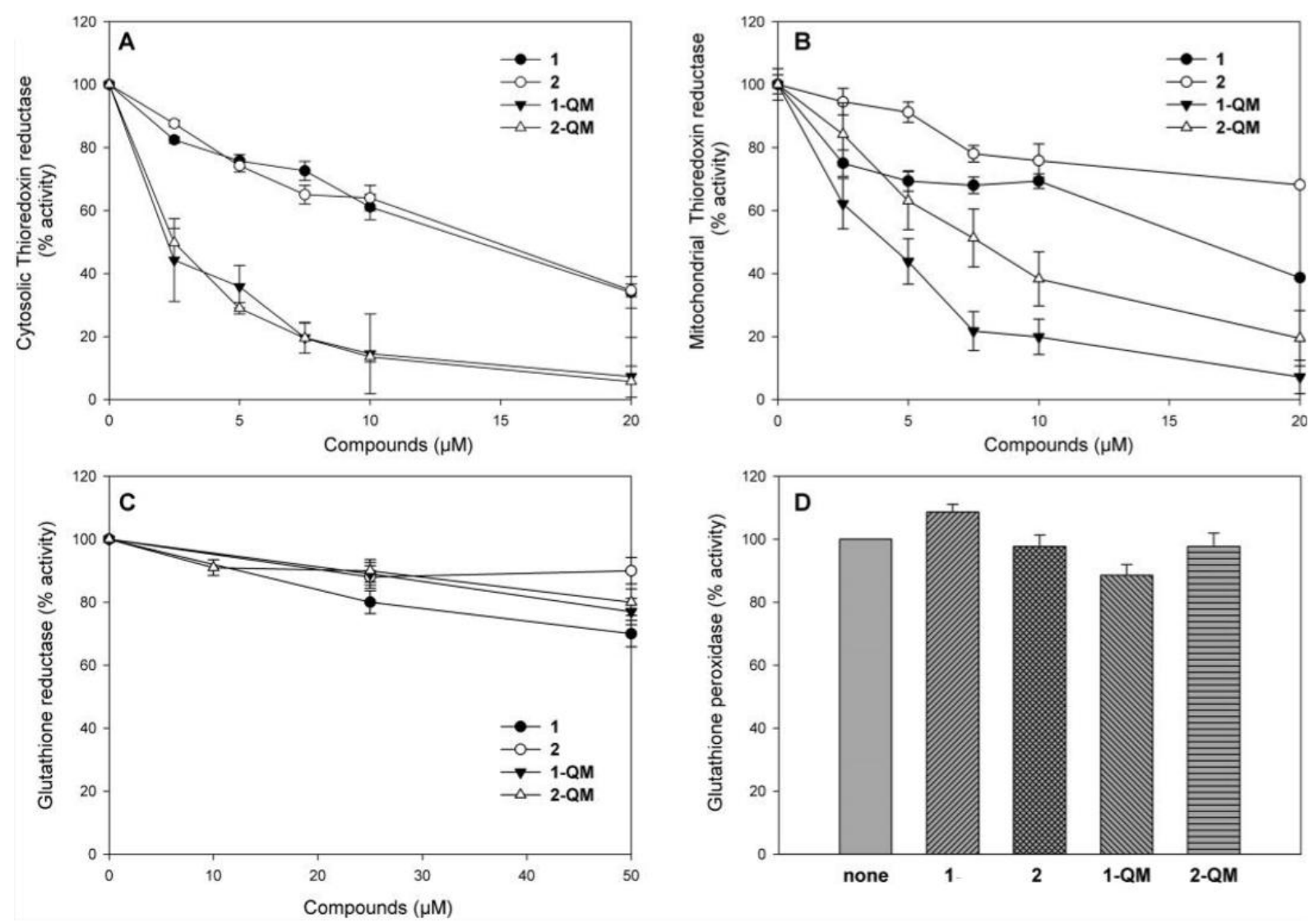

Figure 1. Concentration-dependent effects of the ferrocenyl compounds on the cytosolic (A) and mitochondrial (B) thioredoxin reductases, glutathione reductase (C), and glutathione peroxidase (D). In glutathione peroxidase activity determination (D), the concentration of the various compounds was $20 \mu \mathrm{M}$. Enzymatic activities were measured, after $30 \mathrm{~min}$ of incubation, as indicated in the Experimental Section.

\section{Eff ects of Ferrocenyl Compounds on Isolated Enzymes (TrxR1, TrxR2, GR, and} GPx). The inhibitory eff ect of the ferrocenyl derivatives on the enzymatic activity of purified TrxR1 (cytosolic isoform of thioredoxin reductase) was tested using the DTNB reduction method. As can be seen in Figure 1A, 1-QM and 2-QM were eff ective inhibitors of TrxR1, with $\mathrm{IC}_{50}$ values, after $30 \mathrm{~min}$ of preincubation with the enzyme, of 2.2 and $2.6 \mu \mathrm{M}$, respectively. Under the same experimental conditions, 1 and 2 were far less eff ective, exhibiting $\mathrm{IC}_{50}$ values of 14.4 and $15.0 \mu \mathrm{M}$, respectively, noticeably higher than those of the corresponding quinone methides. At shorter incubation times, 1-QM gave a more rapid inhibitory effect than 2-QM (not shown), however, this effect leveled off at $30 \mathrm{~min}$ incubation. The same compounds were also tested on the mitochondrial isoform of 
thioredoxin reductase (TrxR2) which was still markedly inhibited by $\mathbf{1 - Q M}\left(\mathrm{IC}_{50}=4.2\right.$ $\mu \mathrm{M}$ ), while 2-QM displayed an $\mathrm{IC}_{50}$ value of $7.8 \mu \mathrm{M}$ (Figure $1 \mathrm{~B}$ ). This diff erence of inhibitory efficiency between the two isoforms of TrxR may be due to the diff erent properties of the mitochondrial and cytosolic enzymes (see Discussion).

The ferrocenyl derivatives were also tested as inhibitors of TrxR1 after their in situ oxidation with $\mathrm{H}_{2} \mathrm{O}_{2} / \mathrm{HRP}$ (horseradish peroxidase). As shown in Supporting Information, Figure S1, both compounds 1 and $2(5 \mu \mathrm{M})$ treated with $\mathrm{H}_{2} \mathrm{O}_{2} / \mathrm{HRP}$ completely inhibited TrxR1 activity while $\mathrm{H}_{2} \mathrm{O}_{2}$ or HRP alone were ineff ective. Compounds $\mathbf{1}$ and $\mathbf{2}$ treated with $\mathrm{H}_{2} \mathrm{O}_{2} / \mathrm{HRP}$ showed UV-vis spectra consistent with those of the corresponding quinone methide derivatives obtained by chemical oxidation (Supporting Information, Figure S1).

Glutathione reductase, like thioredoxin reductase, belongs to the family of pyridine nucleotide oxidoreductases but lacks the thiol/selenol motif at the $\mathrm{C}$-terminus. Interestingly, this enzyme was scarcely affected by any of the four compounds (Figure 1C) and a slight inhibition for some of them was observed only at relatively high concentrations.

Like thioredoxin reductase, glutathione peroxidase is also a selenoenzyme containing a selenocysteine in each subunit. ${ }^{53}$ This enzyme is directly concerned with the removal of hydrogen peroxide using reducing equivalents of $\mathrm{GSH}$. The phenols $(\mathbf{1}, \mathbf{2})$ and quinone methides (QM-1, QM-2) did not significantly alter the activity of glutathione peroxidase (Figure 1D). Similar selectivity for TrxR over GPx was previously observed in the case of alkylation-mediated inhibition by acylfulvenes. ${ }^{48}$ Furthermore, to inhibit GPx, some gold complexes such as auranofin are required at relatively high concentrations in comparison to those needed for TrxR. ${ }^{54}$ This inability of the quinone methides to inhibit GPx is probably linked to the fact that, unlike TrxR, the selenol active site is hidden within the enzyme core and consequently unable to interact with the bulky organometallic complexes.

Localization of the Ferrocenyl Compounds Inhibition Site on TrxR1. To obtain information on the type of inhibition exerted on thioredoxin reductase by the ferrocenyl derivatives, a BIAM (biotin-conjugated iodoacetamide) assay was used. This assay makes it possible to evaluate the ability of the compounds to react with the thiol/selenol motif. In fact, BIAM can selectively alkylate TrxR depending on $\mathrm{pH}$. At $\mathrm{pH} 6.0$, only selenocysteine and low $\mathrm{p} K_{\mathrm{a}}$ cysteine can be alkylated, while at $\mathrm{pH} 8.5$, both selenocysteine and cysteine can be derivatized by BIAM. As shown in Figure 2, preincubation of 2-QM at $100 \mu \mathrm{M}$ appeared to 
inhibit almost completely the conjugation of BIAM to TrxR1. Moreover, this inhibition occurred at both $\mathrm{pH} 6.0$ and 8.5, suggesting that 2-QM selectively bound to the selenol moiety at the C-terminus of TrxR1. 1-QM showed a minor eff ect at $\mathrm{pH} 6.0$ and 8.5.

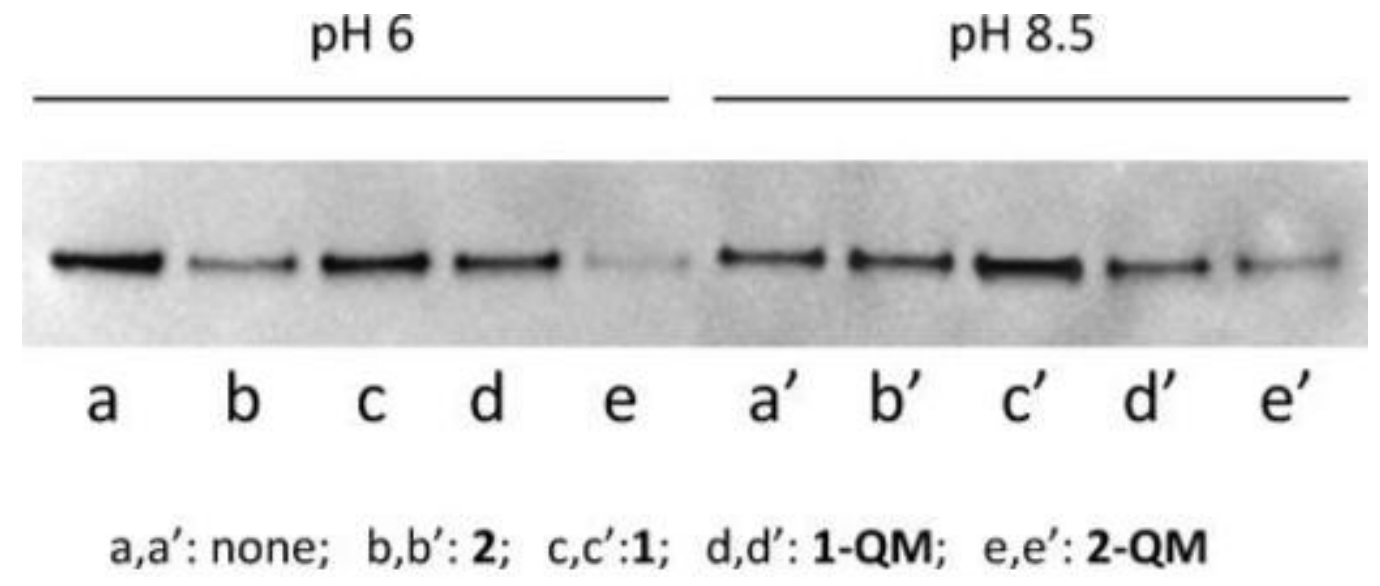

Figure 2. Alkylation with BIAM of TrxR1 treated with the ferrocenyl compounds. TrxR1 $(1 \mu \mathrm{M})$, prereduced with NADPH, was incubated with $100 \mu \mathrm{M}$ ferrocenyl compounds for $30 \mathrm{~min}$. After incubation, aliquots of the reaction mixture were added to $50 \mu \mathrm{M}$ biotinylated iodoacetamide (BIAM) in either $0.1 \mathrm{M}$ Tris- $\mathrm{HCl}$ at $\mathrm{pH} 8.5$ or $0.1 \mathrm{M}$ Hepes-Tris at $\mathrm{pH} 6.0$.

Reaction of Quinone Methides with Cystamine and Selenocystamine. Because of their electrophilic character, quinone methides are notoriously reactive molecules. For instance, Bolton and co-workers reported that the purely organic QM of OHTAM reacted rapidly with GSH under physiological conditions to give a mixture of four adducts resulting from 1,8- and 1,6-Michael additions. Similar reactivity was observed for the quinone methide of metabolite E. ${ }^{55,56}$ To confirm that the inhibition of TrxR by the QMs originated from selective Michael addition to the selenol residue Sec498 at the C-terminus, experiments were performed with two model compounds, namely cystamine and selenocystamine, at neutral $\mathrm{pH}$. Reactions between the organometallic QMs and both substrates (after reduction with TCEP) were monitored by HPLC (Supporting Information, Figures S2-S5), and mixtures were analyzed by ESI-MS (Supporting Information, Figures S6-S9, Table S1). HPLC traces of both 2-QM and its mixture with reduced cystamine displayed three main peaks at 29.7, 31.4, and 32.9 min (Supporting Information, Figure S2), while two extra peaks at 24.1 and 25 min were observed on the chromatogram of the mixture of $\mathbf{2 - Q M}$ and reduced selenocystamine with concomitant decrease of the height of the 29.7 min peak (Supporting Information, Figure S3). Similarly, the HPLC traces of both 1-QM and the mixture of 1-QM and reduced cystamine displayed three peaks at 31, 31.7, and $32.5 \mathrm{~min}$ (Supporting 
Information, Figure S4), while the mixture of 1-QM and reduced selenocystamine displayed two extra peaks at 6.7 and $14.3 \mathrm{~min}$ and almost complete disappearance of the $32.5 \mathrm{~min}$ peak (Supporting Information, Figure S5). Thus, for both QMs, only the selenol aff orded addition products while the thiol was unreactive. ESI-MS analyses confirmed the formation of the Michael addition adducts only in the case of selenocystamine with peaks at $\mathrm{m} / \mathrm{z} 633.4$ and 532.2 for 2-QM and 1-QM, respectively (Supporting Information, Figures S7 and S9). Furthermore, competitive reaction of equimolar amounts of reduced cystamine and selenocystamine with both QMs led only to the formation of the selenide adducts (not shown). On the basis of HPLC analysis, the amount of selenide adduct 4, formed from 2QM, was larger than that formed from 1-QM. We interpret this finding as the highly favored competitive conversion of 1-QM to the indene derivative $\mathbf{5}$ in protic medium (Scheme 2). ${ }^{57}$ The indene adduct in the 1-QM solution was identified as the major peak at $t_{\mathrm{R}}=$ $31 \mathrm{~min}$ by comparative analysis of an authentic sample. Comparatively, 2-QM reproducibly appeared more stable in aqueous medium.

Scheme 2. (A) Reaction of Quinone Methide 2-QM with the selenol $\mathrm{R}_{1} \mathrm{SeH}\left[\mathrm{R}_{1}=\right.$ $\left(\mathrm{CH}_{2}\right)_{2} \mathrm{NH}_{2}$ ]; (B) Competitive Spontaneous Cyclization of 1-QM to Indene 5 in Protic Medium

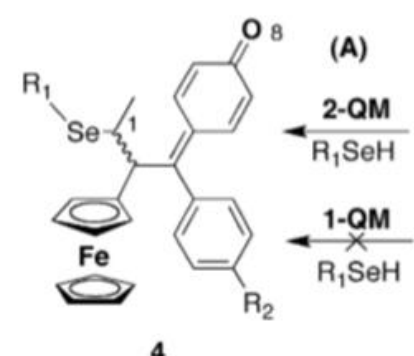

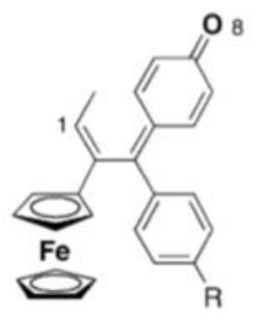

$1-\mathrm{QM}: \mathrm{R}=\mathrm{H}$ 2-QM : $\mathrm{R}=\mathrm{O}\left(\mathrm{CH}_{2}\right)_{3} \mathrm{~N}\left(\mathrm{CH}_{3}\right)_{2}$

(B)
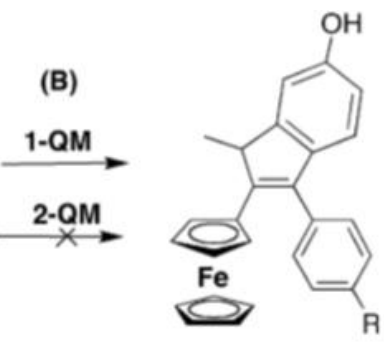

5

Eff ect of the Ferrocenyl Derivatives on Redox Enzyme Activity and on Glutathione Redox State in Tumor Cells. Thioredoxin reductase activity in Jurkat tumor cells was estimated by insulin reduction assay after treatment of cells with 10 or $20 \mu \mathrm{M}$ ferrocenyl compounds for $24 \mathrm{~h}$. As shown in Figure 3A, both $\mathbf{2}$ and 2-QM induced a marked inhibition of TrxR activity in cell lysates. 

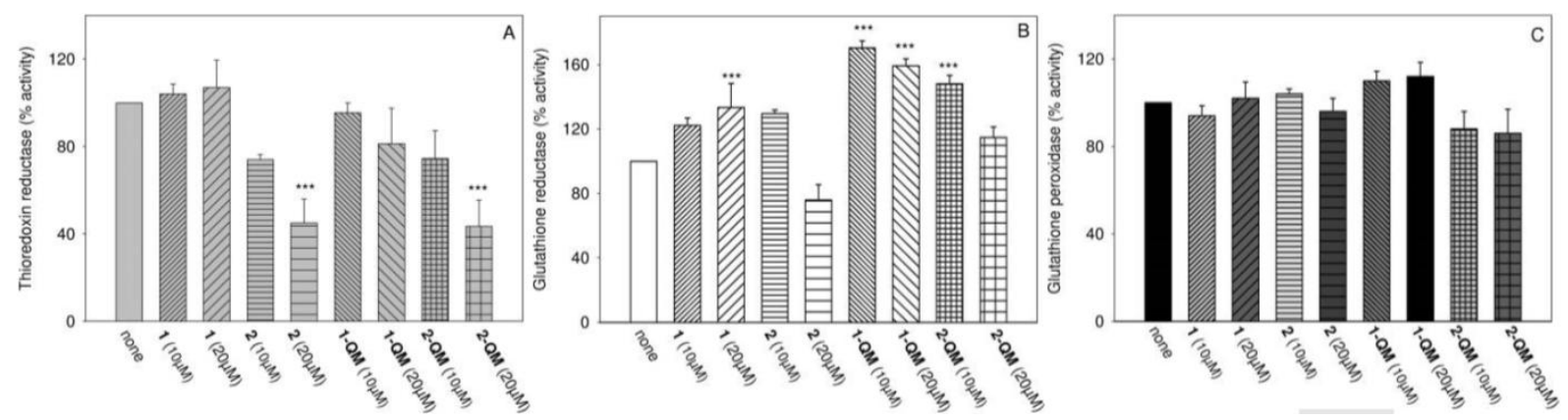

Figure 3. Eff ects of ferrocenyl compounds on thioredoxin reductases (A), glutathione reductase (B), and glutathione peroxidase (C) in cell lysates. Jurkat cells were incubated for $24 \mathrm{~h}$ with 10 or $20 \mu \mathrm{M}$ compounds and lysed. Activities of the redox enzymes were estimated as reported in the Experimental Section.

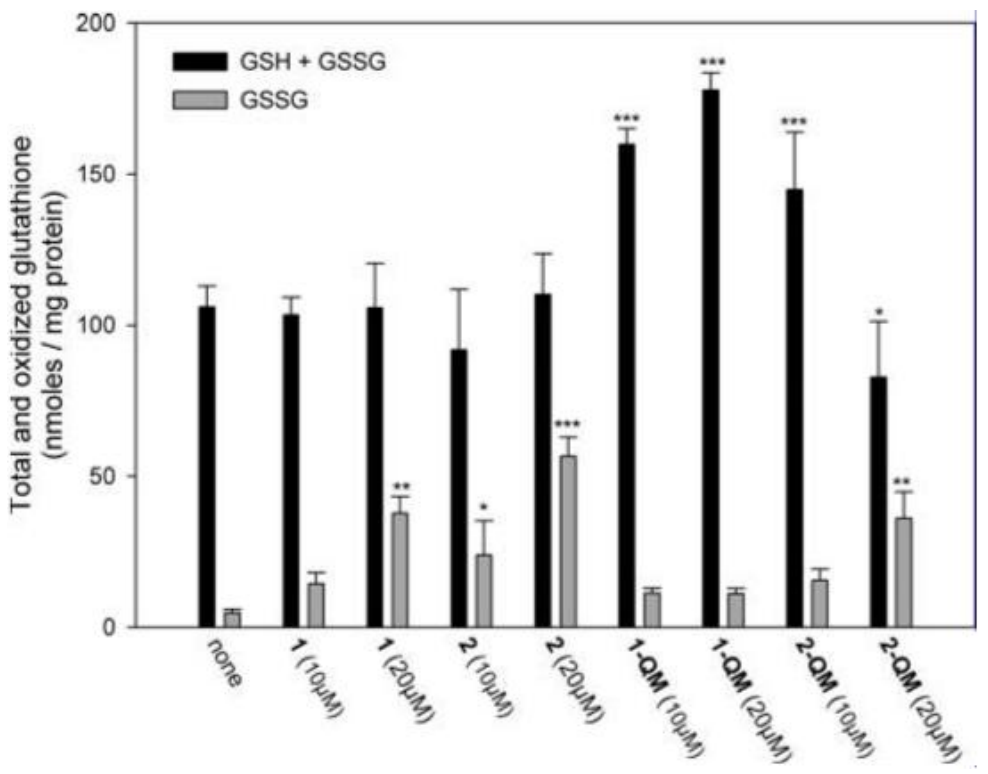

Figure 4. Total (GSH + GSSG) and oxidized (GSSG) glutathione levels in Jurkat cells treated with ferrocenyl compounds. Cells $\left(1 \times 10^{6}\right)$ were treated with the indicated concentrations of ferrocenyl compounds for $24 \mathrm{~h}$ with refresh at $12 \mathrm{~h}$. Cells were then collected and processed as indicated in the Experimental Section.

Under these experimental conditions, 2 and 2-QM inhibited TrxR activity in a concentration-dependent fashion, with about $60 \%$ inhibition at $20 \mu \mathrm{M}$. Conversely, the other two compounds (1 and 1-QM) were scarcely eff ective. Glutathione reductase and peroxidase were essentially not inhibited by ferrocenyl compounds. Rather, in the case of glutathione reductase, there was an increase of activity above the control especially in the presence of quinone methides (Figure 3B). Therefore, the total amounts of glutathione and of oxidized glutathione in cells incubated with the ferrocenyl compounds at 10 or $20 \mu \mathrm{M}$ were determined. As shown in Figure 4, an increase of total glutathione was observed for the 
cells incubated with the quinone methides, except for the higher concentration of 2-QM. The proportion of oxidized glutathione GSSG was also significantly increased in the presence of $\mathbf{2}$ and to a lesser extent in the presence of $\mathbf{1}$ (Figure 4).

\section{Estimation of the Redox State of Cytosolic and Mitochondrial Thioredoxin} in Jurkat Cells after Treatment with the Ferrocenyl Derivatives. The thioredoxin redox system consists of NADPH, thioredoxin reductase, and thioredoxin. The latter, in turn, delivers electrons to several proteins including peroxiredoxins involved in the control of hydrogen peroxide levels. Therefore, inhibition of thioredoxin reductase interrupts the electron flow along the system and may lead to accumulation of the oxidized forms of thioredoxin.

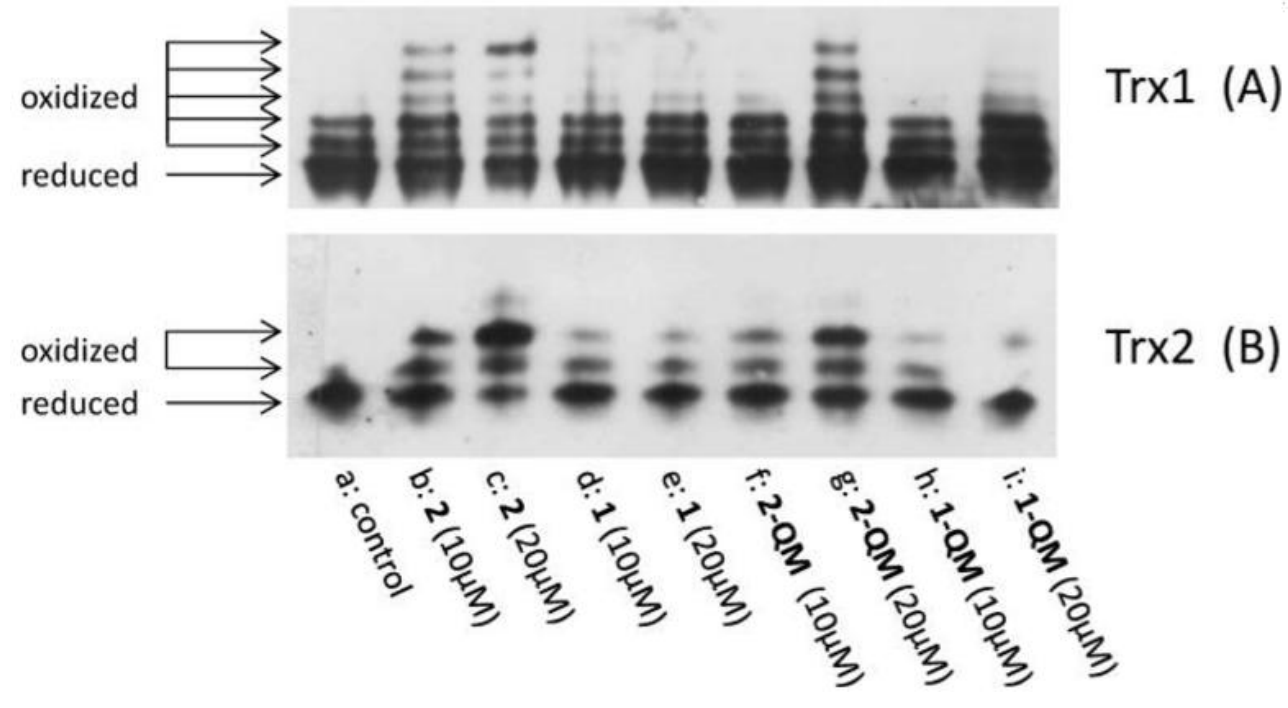

Figure 5. Redox state of cytosolic (A) and mitochondrial (B) thioredoxin of Jurkat cells treated with ferrocenyl compounds. Jurkat cells $\left(2 \times 10^{6}\right)$ in RPMI medium were incubated with the indicated concentrations of ferrocenyl compounds for $24 \mathrm{~h}$ with refresh after $12 \mathrm{~h}$. Lysates were treated with $8 \mathrm{M}$ urea in the presence of $30 \mathrm{mM}$ iodoacetic acid and processed as described in the Experimental Section.

As shown in Figure 5A, the redox condition of cytosolic thioredoxin (Trx1) of Jurkat cells treated with the ferrocenyl compounds $(10$ or $20 \mu \mathrm{M})$ was evaluated by Western blot analysis. The potential oxidation states of $\operatorname{Trx}$ have been extensively analyzed and discussed. ${ }^{58,59}$ Both 2 and 2-QM showed a marked effect on Trx1, as several oxidized and overoxidized states of this protein were clearly observed on the gel. The top band represents the most oxidized form of Trx 1 , which is particularly abundant in lanes b, c, and $g$.

$\mathbf{1}$ and 1-QM were far less eff ective in comparison to the corresponding $\mathbf{2}$ derivatives. Similarly, and consistently with the previous results, $\operatorname{Trx} 2$ was also markedly oxidized in the 
presence of both 2 and 2-QM, while a lower proportion of oxidized forms of Trx2 (but significantly higher than control) was observed for cells incubated with $\mathbf{1}$ and 1-QM (Figure $5 B)$.

\section{DISCUSSION}

Table 1 gives a full overview of the main biochemical results obtained with the ferrocenyl compounds on isolated enzymes and Jurkat cells.

Because quinone methides are reactive species with well-established electrophilicity, it was hypothesized that they could behave as inhibitors of TrxR. Indeed, both QMs under study exhibited an $\mathrm{IC}_{50}$ around $2 \mu \mathrm{M}$ for the cytosolic form of TrxR while their phenol precursors were much less active on both TrxR1 and TrxR2. Subtle diff erences between 2-QM and 1QM were observed on TrxR2, as the former was only half as active as the latter. Even though TrxR1 and TrxR2 share common structural features, they have recently been shown to display subtle differences in substrate selectivity and inhibition by gold compounds. ${ }^{60}$ Other diff erences might be taken into account to explain the selectivity of 2-QM toward TrxR1 such as the more basic character of $\operatorname{TrxR} 2$ with respect to $\operatorname{TrxR} 1^{61}$ and the much higher sensitivity of TrxR1 to calcium ion inhibition with respect to TrxR2. ${ }^{62}$

Further experiments using the BIAM assay suggested that the selenol group of Sec498 was the target of both QMs. Accordingly, the structurally related enzyme glutathione reductase, which contains two Cys residues instead of the C-terminal Cys-Sec motif, was not affected by any of the ferrocenyl compounds. The other important selenoenzyme glutathione peroxidase was also not affected by any of the ferrocenyl compounds, indicating that an accessible selenocysteine residue was required for reaction with the QMs. Model reactions carried out between both QMs and reduced cystamine and selenocystamine confirmed that selective alkylation of selenol occurred at neutral $\mathrm{pH}$ as evidenced by ESI-MS analyses. In contrast, the QMs derived from OHTAM and metabolite E (which is the phenyl analogue of 1) undergo fast reaction with GSH at physiological $\mathrm{pH}$ (half-life of $4 \mathrm{~min}){ }^{55,56}$ This discrepancy is attributable to the lower electrophilic character of the ferrocenyl quinone methides because of the delocalization of positive charge onto the ferrocenyl substituent, which leads to marked selectivity between thiols and selenols. 
Table 1. Summary of the Biological Eff ects Observed in Vitro or in Jurkat Cancer Cells in the Presence of the Ferrocenyl Compounds 1 and 2 and Their Corresponding QMs

\begin{tabular}{|c|c|c|c|c|}
\hline \multirow{2}{*}{\multicolumn{5}{|c|}{$1 \underset{\text { In Vitro Tests }}{\mathbf{2}}$}} \\
\hline & & & & \\
\hline $\mathrm{IC}_{50}$ values on TrxR1 $(\mu \mathrm{M})^{\mathrm{a}}$ & $14.4 \pm 1.8$ & $15.0 \pm 1.1$ & $2.6 \pm 0.7$ & $2.2 \pm 0.5$ \\
\hline $\mathrm{IC}_{50}$ values on $\operatorname{TrxR} 2(\mu \mathrm{M})^{\mathrm{b}}$ & $16.6 \pm 2.2$ & $>20$ & $4.2 \pm 0.8$ & $7.8 \pm 0.9$ \\
\hline$\%$ inhibition of $\mathrm{GR}^{\mathrm{c}}$ & $30.0 \pm 1.6$ & $10.0 \pm 0.8$ & $23.0 \pm 1.2$ & $20.0 \pm 1.1$ \\
\hline$\%$ inhibition of $\mathrm{Gpx}^{\mathrm{d}}$ & 0 & $2.2 \pm 0.1$ & $11.4 \pm 0.4$ & $2.2 \pm 0.1$ \\
\hline ability to react with $\mathrm{Sec}(\mathrm{pH} 6)^{\mathrm{e}}$ & no & $+/$ no & no & ++ \\
\hline reaction with cystamine ( $\mathrm{pH} 6.8$ ) & $n d^{f}$ & $\mathrm{nd}^{\mathrm{f}}$ & no & no \\
\hline reaction with selenocystamine ( $\mathrm{pH} 6.8$ ) & $n d^{f}$ & $\mathrm{nd}^{\mathrm{f}}$ & + & ++ \\
\hline \multicolumn{5}{|c|}{ Tests on Jurkat Cells } \\
\hline$\%$ inhibition of TrxR at $20 \mu \mathrm{M}^{\mathrm{g}}$ & $\approx 0$ & $55.0 \pm 9.5$ & $18.7 \pm 3.6$ & $56.0 \pm 9.3$ \\
\hline$\%$ activity of GR/control at $10 \mu \mathrm{M}$ & $122.0 \pm 4.6$ & $130.0 \pm 2.3$ & $170.0 \pm 4.3$ & $148.0 \pm 5.3$ \\
\hline$\%$ inhibition of Gpx at $20 \mu \mathrm{M}$ & 0 & $4.0 \pm 0.2$ & 0 & $14.0 \pm 1.7$ \\
\hline$\%(\mathrm{GSH}+\mathrm{GSSG}) /$ control at $10 \mu \mathrm{M}$ & $97.5 \pm 1.2$ & $86.6 \pm 12.5$ & $167.6 \pm 4.8$ & $1136.6 \pm 10.2$ \\
\hline$\% \mathrm{GSSG} /(\mathrm{GSH}+\mathrm{GSSG})$ at $10 \mu \mathrm{M}^{\mathrm{n}}$ & $14.0 \pm 1.3$ & $25.0 \pm 8.6$ & $7.0 \pm 0.7$ & $11.0 \pm 4.2$ \\
\hline \multicolumn{5}{|l|}{ presence of oxidized form of: } \\
\hline $\operatorname{Trx} 1$ & \pm & $+++^{1}$ & \pm & +++ \\
\hline $\operatorname{Trx} 2$ & + & $+^{1}$ & + & $+++\mathrm{J}$ \\
\hline
\end{tabular}

The effect of the ferrocenyl complexes on the activity of the same enzymes and the redox state of Trx and GSH was subsequently examined in Jurkat tumor cells. Both 2 and the corresponding QM strongly inhibited total TrxR activity in cell lysates, indicating not only 
that 2 was able to cross the cell membrane, but more importantly, that it underwent oxidation to its quinone methide, which is a much more efficient inhibitor of TrxR. Almost no inhibition of TrxR was observed with 1 or its QM in Jurkat cells. This diff erence of behavior between the two complexes may be related to the inability of $\mathbf{1}$ to convert to its QM in cancer cells and/or to the higher chemical stability of 2-QM with respect to $\mathbf{1 - Q M}$. Indeed, 1-QM was found to rapidly undergo a cyclization reaction aff ording an indene devoid of Michael acceptor reactivity. ${ }^{57}$

Similarly to the isolated enzymes, the activity of glutathione reductase and peroxidase in cell lysates was not altered. On the contrary, stimulation of glutathione reductase activity was observed, particularly with 1-QM. Therefore, the eff ect of the ferrocenyl compounds on the glutathione level and its redox state was examined. It was found that together with GR, the total glutathione content increased, especially upon incubation with the QMs. The increased expression of GR and GSH points to the fact that QMs might stimulate some signaling pathways such as the Keap1-Nrf2 system involved in the regulation of expression of cytoprotective genes. This pathway is well-known to be induced by ROS and electrophiles of both natural and synthetic origins, including Michael acceptors, in a process leading to the expression of genes encoding a broad range of antioxidant enzymes such as peroxidases and enzymes involved in glutathione synthesis. ${ }^{63}$ Compared to the control, the relative proportion of oxidized glutathione was five and three times higher in cells incubated with $\mathbf{2}$ and $\mathbf{1}$, respectively. Because no inhibition of glutathione reductase was simultaneously observed, the high level of GSSG most probably resulted from oxidative stress. This is in full agreement with the high level of ROS detected in MDA-MB-231 breast cancer cells upon incubation of 2 and 1 (Supporting Information, Figure S10). ${ }^{64,65}$

On the other hand, accumulation of oxidized forms of cytosolic and mitochondrial thioredoxins upon incubation with both 2 and its QM correlated well with the inhibition of cellular TrxR by both molecules. According to Du et al., these oxidized forms might be active in redox signaling. ${ }^{59}$ These results again corroborate the fact that $\mathbf{2}$ is able to enter cells and undergoes oxidation to the QM form which appears as the active molecule able to inhibit TrxR and restrict the electron flow toward Trx, therefore stimulating its oxidation. Hence the putative mechanism of action of $\mathbf{2}$ that also rationalizes its cytotoxicity, appears to originate from its intracellular oxidation to the QM. This metabolite acts as an inhibitor of thioredoxin reductase, resulting in the accumulation of oxidized forms of thioredoxin which may in turn 
transmit its oxidized conditions to various cellular targets. Compound $\mathbf{1}$ and its QM appeared to behave differently in that they had scarcely any eff ect on the redox state of Trx1, which again correlates with the previous finding that neither $\mathbf{1}$ nor $\mathbf{1 - Q M}$ significantly inhibited TrxR in Jurkat cells (see above). However, 1 and its QM induced some oxidation of the mitochondrial form of Trx. This selectivity of $\mathbf{1}$ toward Trx 2 may arise from the higher sensitivity of Trx 2 to oxidative stress. ${ }^{66}$ On the whole, the two ferrocifens under study displayed a similar behavior on isolated enzymes but not in cancer cells.

\section{CONCLUSION}

In conclusion, several pieces of biochemical evidence suggesting that the cytotoxicity of 2 originates from its intracellular conversion to an electrophilic quinone methide derivative, first hypothesized in $2006,{ }^{67}$ are provided herein for the first time. Thanks to the presence of the ferrocenyl substituent on 2, the QM was sufficiently stable to enable selective alkylation of TrxR both as isolated enzyme and in Jurkat cells. This study also underscored that 1 behaved diff erently owing to the very short lifetime of its QM in physiological medium that precluded TrxR inhibition in cancer cells. Nevertheless, this study substantiates the unique role of the ferrocenyl entity in the anticancer activity of both $\mathbf{1}$ and $\mathbf{2}$ and shows that activation, at least in part, goes through an intracellular oxidation pathway.

\section{EXPERIMENTAL SECTION}

Synthesis. 1 and 2 were synthesized according to the literature. ${ }^{22,68}$ Other chemicals were purchased from various manufacturers and used as received.

General Remarks. All reactions and manipulations were carried out under an argon atmosphere using standard Schlenk techniques. Acetonitrile was distilled over $\mathrm{P}_{2} \mathrm{O}_{5}$, acetone was dried over $\mathrm{CaCl}_{2}$, diethyl ether was distilled over sodium/benzophenone, and pentane was dried over $4 \AA$ molecular sieves prior to use. $\operatorname{Ag}_{2} \mathrm{O}$ was prepared according to the literature procedure. ${ }^{69}{ }^{1} \mathrm{H}$ and ${ }^{13} \mathrm{C}$ NMR spectra were acquired on a Bruker $300 \mathrm{MHz}$ spectrometer. Mass spectrometry was carried out at the "Service de Spectrometrie de Masse" at ENSCP, Paris. Microanalyses were performed by the "Service de Microanalyse ICSN" at Gif sur Yvette, France. Elemental analysis and NMR were used to determine the purity of the compounds, and the purity of 1-QM and 2-QM was found to be higher than $96 \%$. 
Compound 1 (0.204 g, $0.5 \mathrm{mmol})$ was dissolved in anhydrous acetonitrile $(58 \mathrm{~mL}) . \mathrm{Ag}_{2} \mathrm{O}$ (0.416 g, $1.8 \mathrm{mmol}, 3$ equiv) was added, and the mixture was stirred for $2 \mathrm{~h}$ at room temperature under argon (or nitrogen). The red solution of quinone methide formed was separated from solid by centrifugation and evaporated. A red oil (180 mg, 89\% yield) of quinone methide was obtained. Then $3 \mathrm{~mL}$ of diethyl ether was added to dissolve the quinone methide. The solution was concentrated at about $1.5 \mathrm{~mL}$, and then $5 \mathrm{~mL}$ of pentane were added to precipitate the quinone methide (red oil). The solution was discarded and the quinone methide 1-QM was dried under vacuum. 1-QM was finally isolated as a red solid $(130 \mathrm{mg}) .{ }^{1} \mathrm{H}$ NMR $\left(300 \mathrm{MHz}\right.$, acetone- $d_{6}$; Supporting Information, Figure S11) $\delta 1.67$ (d, $J=$ $7.1 \mathrm{~Hz}, 3 \mathrm{H}, \mathrm{CH}_{3}$ ), 3.96 (s, 5H, $\mathrm{C}_{5} \mathrm{H}_{5}$ ), 4.09 (broad s, $\left.1 \mathrm{H}, \mathrm{C}_{5} \mathrm{H}_{4}\right), 4.11$ (broad s, $1 \mathrm{H}, \mathrm{C}_{5} \mathrm{H}_{4}$ ), 4.15 (broad s, $\left.1 \mathrm{H}, \mathrm{C}_{5} \mathrm{H}_{4}\right), 4.26$ (broad s, $\left.1 \mathrm{H}, \mathrm{C}_{5} \mathrm{H}_{4}\right), 6.34-6.41\left(\mathrm{~m}, 2 \mathrm{H}, \mathrm{C}_{6} \mathrm{H}_{4}\right), 6.42$ (q, $J=$ $7.1 \mathrm{~Hz}, 1 \mathrm{H}, \mathrm{CH}=), 7.46-7.53\left(\mathrm{~m}, 6 \mathrm{H}, \mathrm{C}_{6} \mathrm{H}_{5}+\mathrm{C}_{6} \mathrm{H}_{4}\right), 7.61\left(\mathrm{dd}, J=9.9\right.$ and $\left.2.6 \mathrm{~Hz}, 1 \mathrm{H}, \mathrm{C}_{6} \mathrm{H}_{4}\right)$. ${ }^{13} \mathrm{C}$ NMR (75.46 MHz, acetone- $d_{6}$; Supporting Information, Figure S12): $\delta=15.9(\mathrm{Me}), 68.9$ $\left(2 \mathrm{CH}, \mathrm{C}_{5} \mathrm{H}_{4}\right), 70.0\left(7 \mathrm{CH}, \mathrm{C}_{5} \mathrm{H}_{4}+\mathrm{C}_{5} \mathrm{H}_{5}\right), 88.0\left(\mathrm{C}_{5} \mathrm{H}_{4}, \mathrm{C}_{\mathrm{ip}}\right), 125.5(\mathrm{CH}), 129.4(2 \mathrm{CH}$, $\left.\mathrm{C}_{6} \mathrm{H}_{5}\right), 129.5(\mathrm{CH}), 129.7(\mathrm{CH}), 130.7(\mathrm{CH}), 131.6\left(2 \mathrm{CH}, \mathrm{C}_{6} \mathrm{H}_{5}\right), 138.3(\mathrm{CH}), 138.9$ (C), 139.1 (C), 139.7 (CH), 146.0 (C), 157.5 (C), 186.9 (CO). MS (CI; Supporting Information, Figure S13): $m / z=407.22[\mathrm{M}+\mathrm{H}]^{+}$. Anal. Calcd for $\mathrm{C}_{26} \mathrm{H}_{22} \mathrm{FeO} \cdot 0.2 \mathrm{H}_{2} \mathrm{O}: \mathrm{C}$, 76.18; H, 5.51. Found: C, 76.07; H, 5.25.

p-[(Z)-1-(p-Dimethylaminopropyloxyphenyl)-2-ferrocenyl-2-butenylidene]benzenone, 2QM. Compound 2 (0.204 g, $0.4 \mathrm{mmol})$ was dissolved in dry acetone $(10 \mathrm{~mL}) . \mathrm{Ag}_{2} \mathrm{O}(0.277 \mathrm{~g}$, $1.2 \mathrm{mmol}$ ) was added, and the mixture was stirred for $1 \mathrm{~h}$ at room temperature. The red solution of quinone methide formed was separated from the solid by centrifugation and evaporated. A red oil (180 mg, 88\% yield) of quinone methide was obtained. Three $\mathrm{mL}$ of diethyl ether was added to dissolve the quinone methide. The solution was concentrated at about $1.5 \mathrm{~mL}$, and then $5 \mathrm{~mL}$ of pentane were added to precipitate the quinone methide (red oil). The solution was discarded, and the quinone methide 2-QM was dried under vacuum. 2QM was finally isolated as a red solid $(120 \mathrm{mg}) .{ }^{1} \mathrm{H} \mathrm{NMR}$ (300 $\mathrm{MHz}$, acetone- $d_{6}$; Supporting Information, Figure S14): $1.64\left(\mathrm{~d}, J=7.1 \mathrm{~Hz}, 3 \mathrm{H}, \mathrm{CH}_{3}\right), 1.91\left(\mathrm{~m}, 2 \mathrm{H}, \mathrm{CH}_{2}\right), 2.15$ (s, 6H, $\mathrm{NMe}_{2}$ ), 2.39 (t, $J=6.8 \mathrm{~Hz}, 2 \mathrm{H}, \mathrm{CH}_{2}$ ), 3.97 (s, 5H, $\mathrm{C}_{5} \mathrm{H}_{5}$ ), 4.06 (broad s, $1 \mathrm{H}, \mathrm{C}_{5} \mathrm{H}_{4}$ ), 4.10-4.15 (m, $\left.2 \mathrm{H}+2 \mathrm{H}, \mathrm{OCH}_{2}+\mathrm{C}_{5} \mathrm{H}_{4}\right), 4.26$ (broad s, $\left.1 \mathrm{H}, \mathrm{C}_{5} \mathrm{H}_{4}\right), 6.33-6.38(\mathrm{~m}, 2 \mathrm{H}$, $\left.\mathrm{C}_{6} \mathrm{H}_{4}\right), 6.41$ (q, $\left.J=7.1 \mathrm{~Hz}, 1 \mathrm{H}, \mathrm{CH}=\right), 7.08\left(\mathrm{~d}, J=8.8 \mathrm{~Hz}, 2 \mathrm{H}, \mathrm{C}_{6} \mathrm{H}_{4}\right), 7.46(\mathrm{~d}, \mathrm{~J}=8.8 \mathrm{~Hz}$, $\left.2 \mathrm{H}, \mathrm{C}_{6} \mathrm{H}_{4}\right), 7.56\left(\mathrm{q}, J=15.5\right.$ and $\left.3.00 \mathrm{~Hz}, 1 \mathrm{H}, \mathrm{C}_{6} \mathrm{H}_{4}\right), 7.59(\mathrm{q}, J=15.5$ and $3.00 \mathrm{~Hz}, 1 \mathrm{H}$, 
$\mathrm{C}_{6} \mathrm{H}_{4}$ ). MS (CI; Supporting Information, Figure S15): $m / z=508.34[\mathrm{M}+\mathrm{H}]^{+}$. Anal. Calcd for $\mathrm{C}_{31} \mathrm{H}_{33} \mathrm{FeNO}_{2}$ : C, 73.37; H, 6.55; N, 2.76. Found: C, 73.34; H, 6.74; N, 2.65.

Estimation of Isolated Enzyme Activities. Highly purified cytosolic thioredoxin reductase (TrxR1) was prepared from rat liver according to the method of Luthman and Holmgren. ${ }^{35}$ Mitochondrial thioredoxin reductase (TrxR2) was purified from isolated rat liver mitochondria following the procedure of Rigobello and Bindoli. ${ }^{70}$

Thioredoxin reductases activity was determined by estimating the DTNB-reducing property of the enzymes in the presence of NADPH. Aliquots of highly purified TrxR1 (60 $\mathrm{nM})$ or TrxR2 $(60 \mathrm{nM})$ in $0.2 \mathrm{M}$ Tris $\mathrm{HCl}$ buffer $(\mathrm{pH} 8.1), 1 \mathrm{mM}$ EDTA, and $0.05 \mathrm{mM}$ NADPH were preincubated for $30 \mathrm{~min}$ with the various compounds. Afterward, $0.2 \mathrm{mM}$ NADPH was further added, and the reaction was initiated with $1 \mathrm{mM}$ DTNB and monitored spectrophotometrically at $412 \mathrm{~nm}$ for about $10 \mathrm{~min}$. Yeast glutathione reductase activity was measured in 0.2 M Tris-HCl buff er (pH 8.1), 1 mM EDTA, and $0.25 \mathrm{mM} \mathrm{NADPH}$ after $30 \mathrm{~min}$ of preincubation with the various compounds. The assay was initiated by addition of $1 \mathrm{mM}$ GSSG and followed spectrophotometrically at $340 \mathrm{~nm}$. Glutathione peroxidase activity was evaluated by adaptation of current assays. ${ }^{48,71} \mathrm{GPx}$ from bovine erythrocytes (0.02 U) was incubated with $20 \mu \mathrm{M}$ ferrocenyl compounds in a total volume of $0.5 \mathrm{~mL}$ of $50 \mathrm{mM}$ Hepes buff er (pH 7.0) containing $3 \mathrm{mM}$ EDTA and $0.3 \mathrm{mM} \mathrm{NADPH}$ at $25^{\circ} \mathrm{C}$. After $30 \mathrm{~min}, 4 \mathrm{mM}$ GSH and $25 \mathrm{nM}$ yeast glutathione reductase were added. After $2 \mathrm{~min}$ of incubation, the reaction was started by the addition of $200 \mu \mathrm{M}$ tert-butyl hydroperoxide and followed at $340 \mathrm{~nm}$ by the decrease of NADPH absorption.

BIAM Assay. TrxR1 $(1 \mu \mathrm{M})$, prereduced in the presence of $60 \mu \mathrm{M}$ NADPH, was incubated with $3 \mu \mathrm{L}$ of freshly prepared $1 \mathrm{mM}$ stock solution (100 $\mu \mathrm{M}$ final concentration) of ferrocenyl compounds for $30 \mathrm{~min}$ at room temperature in $20 \mathrm{mM}$ Tris- $\mathrm{HCl}$ buff er ( $\mathrm{pH} 7.4$ ) containing $200 \mu \mathrm{M}$ NADPH and $1 \mathrm{mM}$ EDTA. After incubation, $8 \mu \mathrm{L}$ of the reaction mixture were removed and added to $50 \mu \mathrm{M}$ biotinylated iodoacetamide (BIAM) in either $0.1 \mathrm{M}$ Tris- $\mathrm{HCl}$ at $\mathrm{pH} 8.5$ or $0.1 \mathrm{M}$ Hepes-Tris at $\mathrm{pH}$ 6.0. Samples were incubated at room temperature for additional $30 \mathrm{~min}$ to alkylate the remaining $-\mathrm{SH}$ groups of the enzyme. ${ }^{72}$ Then aliquots of BIAM-modified enzyme were loaded without reducing agent onto BisTris Gel NUPAGE (12\%) and transferred to a nitrocellulose membrane. Proteins labeled with BIAM were detected with horseradish peroxidase-conjugated streptavidin and enhanced chemiluminescence detection. 


\section{Reaction of the Quinone Methides with Thiol and Selenol.}

The disulfide cystamine and the diselenide selenocystamine were treated with 2 equiv TCEP (tris(2-carboxyethyl)phosphine) in triethanolamine buffer $\mathrm{pH} 6.8$ to reduce them into the corresponding thiol/selenol. After a few minutes, the quinone methides in solution in $\mathrm{MeCN}$ were added (final concentration $1 \mathrm{mM}, 0.1$ equiv with respect to thiol/selenol). The final reaction mixtures contained $50 \% \mathrm{MeCN}$. The reaction outcomes were monitored by RPHPLC with UV detection on a $150 \mathrm{~mm} \times 2 \mathrm{~mm}$ Nucleodur Gravity C18 column $5 \mu \mathrm{m}$ (Macherey-Nagel). Species were eluted using a gradient from 10 to $80 \% \mathrm{MeCN}-0.1 \%$ TFA in $\mathrm{H}_{2} \mathrm{O}-0.1 \%$ TFA in 30 min (for 2-QM) or a gradient from 40 to $90 \% \mathrm{MeCN}-0.1 \%$ TFA in $\mathrm{H}_{2} \mathrm{O}-0.1 \%$ TFA in $25 \mathrm{~min}$ (for $\mathbf{1 - Q M}$ ) at $0.25 \mathrm{~mL} / \mathrm{min}$. After several hours, the mixtures were analyzed by ESI-MS.

\section{Determination of Thioredoxin Reductases, Glutathione Reductase, and} Glutathione Peroxidase in Cell Lysates. Jurkat cells were grown at $37{ }^{\circ} \mathrm{C}$ in $5 \%$ carbon dioxide atmosphere using RPMI 1640 medium containing 10\% fetal calf serum and supplemented with $2 \mathrm{mM}$ L-glutamine.

Jurkat cells $\left(2 \times 10^{6}\right)$ were incubated with 10-20 $\mu \mathrm{M}$ compounds for $24 \mathrm{~h}$ with refresh after 12 h. After incubation, cells were harvested and washed with PBS. Each sample was lysed with a modified RIPA buffer: $150 \mathrm{mM} \mathrm{NaCl}, 50 \mathrm{mM}$ Tris-HCl, $1 \mathrm{mM}$ EDTA, $0.1 \%$ SDS, 0.5\% DOC, $1 \mathrm{mM} \mathrm{NaF}$, and an antiprotease cocktail ("Complete" Roche, Mannheim, Germany) containing $0.1 \mathrm{mM}$ PMSF. After $40 \mathrm{~min}$ of incubation at $0{ }^{\circ} \mathrm{C}$, lysates were centrifuged at $14000 \mathrm{~g}$ for $5 \mathrm{~min}$. The supernatants were tested for enzyme activities. Aliquots of lysates were subjected to thioredoxin reductase determination with the insulin reduction test. $^{73}$ Briefly, $12 \mu \mathrm{g}$ proteins of cell lysates were incubated for $40 \mathrm{~min}$ in a final volume of 50 $\mu \mathrm{L}$ in $100 \mathrm{mM}$ Hepes buffer (pH 7.6) and in the presence of 15 mM EDTA, $1.5 \mathrm{mM}$ NADPH, $0.25 \mathrm{mM}$ insulin, and $100 \mu \mathrm{M}$ Trx from Escherichia coli. The reaction was stopped by addition of $0.2 \mathrm{~mL}$ of $1 \mathrm{mM}$ DTNB in $0.2 \mathrm{M}$ Tris- $\mathrm{HCl}$ buffer $(\mathrm{pH} \mathrm{8.1)} \mathrm{containing} 1 \mathrm{mM}$ EDTA and 7.2 M guanidine, and samples were estimated at $412 \mathrm{~nm}$.

Glutathione reductase activity was measured at $25{ }^{\circ} \mathrm{C}$ on $80 \mu \mathrm{g}$ protein $/ \mathrm{mL}$ as reported above. Glutathione peroxidase activity was determined in $400 \mu \mathrm{g}$ protein/mL of lysate in a final volume of $0.25 \mathrm{~mL}$ of $0.2 \mathrm{M}$ Tris- $\mathrm{HCl}$ buff er $(\mathrm{pH} 8.1)$ and $1 \mathrm{mM}$ EDTA as described above. 
Glutathione Redox State Estimation in Cell Lysates. First, $1 \times 10^{6}$ Jurkat cells in complete medium were incubated for $24 \mathrm{~h}$ with refresh at $12 \mathrm{~h}$. Then cells were collected, washed twice with cold PBS, and then lysed and deproteinized with 6\% meta-phosphoric acid. After $10 \mathrm{~min}$ at $4{ }^{\circ} \mathrm{C}$, samples were centrifuged and supernatants were neutralized with $15 \% \mathrm{Na}_{3} \mathrm{PO}_{4}$ and assayed for total glutathione. ${ }^{74}$ Sample aliquots were derivatized with 2vinylpyridine $^{75}$ in order to block reduced glutathione, and oxidized glutathione was then estimated. Protein concentration was determined by the Lowry et al. assay ${ }^{76}$ in deproteinized samples washed with $1 \mathrm{~mL}$ of ice-cold acetone, centrifuged at $11000 \mathrm{~g}$, dried, and then dissolved in $62.5 \mathrm{mM}$ Tris/ $\mathrm{HCl}$ buff er (pH 8.1) containing 1\% SDS.

Redox Western Blot Analysis of Trx1 and Trx2. The redox state of Trx was detected using a modified Western blot analysis. ${ }^{58,77}$ Briefly, to determine the redox state of thioredoxin, after cell treatment with 10 or $20 \mu \mathrm{M}$ ferrocenyl compounds for $24 \mathrm{~h}$ with refresh after $12 \mathrm{~h}, 2$ $\times 10^{6}$ Jurkat cells after two washings with PBS were lysed in $150 \mu \mathrm{L}$ of urea lysis buff er $(100$ $\mathrm{mM}$ Tris-HCl, $\mathrm{pH} 8.3$ ) containing $1 \mathrm{mM}$ EDTA, $8 \mathrm{M}$ urea, and $30 \mathrm{mM}$ IAA in order to alkylate free thiols. Incubation was carried out at $37{ }^{\circ} \mathrm{C}$ for $30 \mathrm{~min}$. After centrifugation, the cell lysates were precipitated by ice-cold acetone-1 $\mathrm{N} \mathrm{HCl} \mathrm{(98:2).} \mathrm{The} \mathrm{precipitate} \mathrm{was} \mathrm{washed}$ twice with ice-cold acetone- $1 \mathrm{~N} \mathrm{HCl}-\mathrm{H}_{2} \mathrm{O}$ (98:2:10) and resuspended in $70 \mu \mathrm{L}$ of urea lysis buffer including $3.5 \mathrm{mM}$ DTT and incubated for $30 \mathrm{~min}$ at $37{ }^{\circ} \mathrm{C}$. Afterward, $3.5 \mu \mathrm{L}$ of 200 mM IAM were added to the various samples, followed by incubation for $15 \mathrm{~min}$ at $37^{\circ} \mathrm{C}$. Protein concentration was determined by the Lowry assay. ${ }^{76}$ Proteins were separated by ureaPAGE gel (7\% acrylamide/bis(acrylamide) in $8 \mathrm{M}$ urea) and blotted using Turbo System (Bio-Rad Laboratories, Hercules, CA, USA). Membranes were probed with the primary antibodies respectively for Trx1 (FL 105) and for Trx2 (H75) (Santa Cruz Biotechnology, Santa Cruz, CA, USA).

Statistical Analysis. All the values are the mean \pm SD of not less than five measurements. Multiple comparisons were made by one-way analysis of variance followed by the Tukey-Kramer multiple comparison test.

\section{ASSOCIATED CONTENT}

\section{Supporting Information}


UV-vis spectra of oxidized ferrocenyl compounds and in situ inhibition of TrxR1; HPLC and ESI-MS spectra of mixtures; ROS measurements; ${ }^{1} \mathrm{H}$ NMR, ${ }^{13} \mathrm{C}$ NMR, MS of 1-QM and ${ }^{1} \mathrm{H}$ NMR, MS of 2-QM; compound directory (CSV). This material is available free of charge via the Internet at http://pubs.acs.org.

\section{AUTHOR INFORMATION}

\section{Corresponding Authors}

*For G.J.: phone, +33 143269555; E-mail, gerard.jaouen@ chimie-paristech.fr.

*For M.P.R.: phone, +39 049 8276138; E-mail, mariapia. rigobello@unipd.it.

\section{Notes}

The authors declare no competing financial interest.

\section{ACKNOWLEDGMENTS}

We acknowledge COST Actions CM1105 and CM1106 for financial support and for fostering fruitful discussions among authors. We also acknowledge PRIN 20107Z8XBW granted by the Ministero dell'Istruzione, Universita e Ricerca (MIUR) Italy, and CPDA130272 granted by University of Padova (Italy). We also acknowledge the Agence Nationale de la Recherche (grant no. ANR-10-BLAN-706; Mecaferrol) for financial support, Jan-Martin Heldt for ROS measurements, and B. McGlinchey for correction of the manuscript.

\section{ABBREVIATIONS USED}

BIAM, biotinylated iodoacetamide; DTNB, 5,5'-dithiobis(2-nitrobenzoic acid); DTT, dithiothreitol; ER, estrogen receptor; GPx, glutathione peroxidase; GR, glutathione reductase; GSH, reduced glutathione; GSSG, oxidized glutathione; HRP, horseradish peroxidase; IAA, iodoacetic acid; IAM, iodoacetamide; NHC, $N$-heterocyclic carbene; OHTAM, 4hydroxytamoxifen; ROS, reactive oxygen species; QM, quinone methide; Sec, selenocysteine residue; Trx1, thioredoxin 1 (cytosolic); Trx2, thioredoxin 2 (mitochondrial); TrxR1, thioredoxin reductase 1 (cytosolic); TrxR2, thioredoxin reductase 2 (mitochondrial) 


\section{REFERENCES}

(1) Savage, P.; Stebbing, J.; Bower, M.; Crook, T. Why does cytotoxic chemotherapy cure only some cancers? Nature Clin. Pract. Oncol. 2009, 6, 43-52.

(2) Reedijk, J. Platinum anticancer coordination compounds: study of DNA binding inspires new drug design. Eur. J. Inorg. Chem. 2009, 1303-1312.

(3) Dyson, P. J.; Sava, G. Metal-based antitumour drugs in the post genomic era. Dalton Trans. 2006, 1929-1933.

(4) Sava, G.; Jaouen, G.; Hillard, E. A.; Bergamo, A. Targeted therapy vs DNA-adduct formation-guided design: thoughts about the future of metal-based anticancer drugs. Dalton Trans. 2012, 41, 8226-8234.

(5) Hillard, E. A.; Jaouen, G. Bioorganometallics: future trends in drug discovery, analytical chemistry, and catalysis. Organometallics 2011, 30, 20-27.

(6) Jaouen, G.; Vessieres, A.; Top, S.; Ismail, A. A.; Butler, I. S. Metal-carbonyl fragments as a new class of markers in molecular-biology. J. Am. Chem. Soc. 1985, 107, 4778-4780.

(7) Jaouen, G.; Beck, W.; McGlinchey, M. J. A novel field of research: bioorganometallic chemistry, origins, and founding principles. In Bioorganometallics: Biomolecules, Labeling, Medicine; Jaouen, G., Ed.; Wiley: New York, 2006; pp 1-37.

(8) Hillard, E. A., Vessieres, A., Jaouen, G. Ferrocene functionalized endocrine modulators for the treatment of cancer. In Medicinal Organometallic Chemistry, Topics in Organometallic Chemistry; Jaouen, G., Metzler-Nolte, N., Eds.; Springer-Verlag: Berlin, 2010; vol 32, pp 81-117.

(9) Gasser, G.; Ott, I.; Metzler-Nolte, N. Organometallic anticancer compounds. J. Med. Chem. 2011, 54, 3-25.

(10) Dör, M.; Meggers, E. Metal complexes as structural templates for targeting proteins. Curr. Opin. Chem. Biol. 2014, 19, 76-81.

(11) Barry, N. P. E.; Sadler, P. J. Exploration of the medical periodic table: towards new 
targets. Chem. Commun. 2013, 49, 5106-5131.

(12) Casini, A.; Gabbiani, C.; Sorrentino, F.; Rigobello, M. P.; Bindoli, A.; Geldbach, T. J.; Marrone, A.; Re, N.; Hartinger, C. G.; Dyson, P. J.; Messori, L. Emerging protein targets for anticancer metallodrugs: inhibition of thioredoxin reductase and cathepsin B by antitumor ruthenium(II)-arene compounds. J. Med. Chem. 2008, 51, 6773-6781.

(13) De Luca, A.; Hartinger, C. G.; Dyson, P. J.; Lo Bello, M.; Casini, A. A new target for gold(I) compounds: glutathione-S-transferase inhibition by auranofin. J. Inorg. Biochem. 2013, $119,38-42$.

(14) Rubbiani, R.; Schuh, E.; Meyer, A.; Lemke, J.; Wimberg, J.; Metzler-Nolte, N.; Meyer, F.; Mohr, F.; Ott, I. TrxR inhibition and antiproliferative activities of structurally diverse gold $N$-heterocyclic carbene complexes. MedChemComm 2013, 4, 942-948.

(15) Oehninger, L.; Stefanopoulou, M.; Alborzinia, H.; Schur, J.; Ludewig, S.; Namikawa, K.; Muñoz-Castro, A.; Köster, R. W.; Baumann, K.; Wölfl, S.; Sheldrick, W. S.; Ott, I. Evaluation of arene ruthenium(II) $N$-heterocyclic carbene complexes as organometallics interacting with thiol and selenol containing biomolecules. Dalton Trans. 2013, 42, $1657-1666$.

(16) Schuh, E.; Pflüger, C.; Citta, A.; Folda, A.; Rigobello, M. P.; Bindoli, A.; Casini, A.; Mohr, F. Gold(I) carbene complexes causing thioredoxin 1 and thioredoxin 2 oxidation as potential anticancer agents. J. Med. Chem. 2012, 55, 5518-5528.

(17) Zou, T.; Lum, C. T.; Lok, C.-N.; To, W.-P.; Low, K.-H.; Che, C.-M. A binuclear gold(I) complex with mixed bridging diphosphine and bis( $N$-heterocyclic carbene) ligands shows favorable thiol reactivity and inhibits tumor growth and angiogenesis in vivo. Angew. Chem., Int. Ed. 2014, 53, 5810-5814.

(18) Top, S.; Tang, J.; Vessieres, A.; Carrez, D.; Provot, C.; Jaouen, G. Ferrocenyl hydroxytamoxifen: a prototype for a new range of oestradiol receptor site-directed cytotoxics. Chem. Commun. 1996, 955-956.

(19) Top, S.; Dauer, B.; Vaissermann, J.; Jaouen, G. Facile route to ferrocifen, 1-[4-(2dimethylaminoethoxy)]-1-(phenyl-2-ferrocenyl-but-1-ene), first organometallic analogue of 
tamoxifen, by the McMurry reaction. J. Organomet. Chem. 1997, 541, 355-361.

(20) Top, S.; Kaloun, E. B.; Toppi, S.; Herrbach, A.; McGlinchey, M. J.; Jaouen, G. Decomplexation of cyclopentadienylmanganese tricarbonyls under very mild conditions: a novel route to substituted cyclopentadienes and their application in organometallic synthesis. Organometallics 2001, 20, 4554-4561.

(21) Nguyen, A.; Vessieres, A.; Hillard, E. A.; Top, S.; Pigeon, P.; Jaouen, G. Ferrocifens and ferrocifenols as new potential weapons against breast cancer. Chimia 2007, 61, 716-724.

(22) Top, S.; Vessieres, A.; Leclercq, G.; Quivy, J.; Tang, J.; Vaissermann, J.; Huché, M.; Jaouen, G. Synthesis, biochemical properties and molecular modelling studies of organometallic specific estrogen receptor modulators (SERMs), the ferrocifens and hydroxyferrocifens: evidence for an antiproliferative effect of hydroxyferrocifens on both hormone-dependent and hormone-independent breast cancer cell lines. Chem.-Eur. J. 2003, 9, $5223-5236$.

(23) Vessieres, A. Metal carbonyl tracers and the ferrocifen family: two facets of bioorganometallic chemistry. J. Organomet. Chem. 2013, 734, 3-16.

(24) Gormen, M.; Pigeon, P.; Top, S.; Vessieres, A.; Plamont, M. A.; Hillard, E. A.; Jaouen, G. Facile synthesis and strong antiproliferative activity of disubstituted diphenylmethylidenyl[3]ferrocenophanes on breast and prostate cancer cell lines. MedChemComm 2010, 1, 149151.

(25) Michard, Q.; Jaouen, G.; Vessieres, A.; Bernard, B. A. Evaluation of cytotoxic properties of organometallic ferrocifens on melanocytes, primary and metastatic melanoma cell lines. J. Inorg. Biochem. 2008, 102, 1980-1985.

(26) Allard, E.; Passirani, C.; Garcion, E.; Pigeon, P.; Vessieres, A.; Jaouen, G.; Benoit, J. P. Lipid nanocapsules loaded with an organometallic tamoxifen derivative as a novel drug-carrier system for experimental malignant gliomas. J. Controlled Release 2008, 130, $146-153$.

(27) Allard, E.; Huynh, N. T.; Vessieres, A.; Pigeon, P.; Jaouen, G.; Benoit, J. P.; Passirani, C. Dose effect activity of ferrocifen-loaded lipid nanocapsules on a 9L-glioma model. Int. J. 
Pharm. 2009, 379, 317-323.

(28) Laine, A. L.; Adriaenssens, E.; Vessieres, A.; Jaouen, G.; Corbet, C.; Desruelles, E.; Pigeon, P.; Toillon, R. A.; Passirani, C. The in vivo performance of ferrocenyl tamoxifen lipid nanocapsules in xenografted triple negative breast cancer. Biomaterials 2013, 34, 6949-6956.

(29) Hamels, D.; Dansette, P. M.; Hillard, E. A.; Top, S.; Vessieres, A.; Herson, P.; Jaouen, G.; Mansuy, D. Ferrocenyl quinone methides as strong antiproliferative agents: formation by metabolic and chemical oxidation of ferrocenyl phenols. Angew. Chem., Int. Ed. 2009, 48, 9124-9126.

(30) Hillard, E.; Vessieres, A.; Thouin, L.; Jaouen, G.; Amatore, C. Ferrocene-mediated proton-coupled electron transfer in a series of ferrocifen-type breast-cancer drug candidates. Angew. Chem., Int. Ed. 2006, 45, 285-290.

(31) Messina, P.; Labbe, E.; Buriez, O.; Hillard, E. A.; Vessieres, A.; Hamels, D.; Top, S.; Jaouen, G.; Frapart, Y. M.; Mansuy, D.; Amatore, C. Deciphering the activation sequence of ferrociphenol anticancer drug candidates. Chem.-Eur. J. 2012, 18, 6581-6587.

(32) Arnér, E. S. J. Focus on mammalian thioredoxin reductases-important selenoproteins with versatile functions. Biochim. Biophys. Acta 2009, 1790, 495-526.

(33) Holmgren, A.; Lu, J. Thioredoxin and thioredoxin reductase: current research with special reference to human disease. Biochem. Biophys. Res. Commun. 2010, 396, 120-124.

(34) Rhee, S. G.; Kang, S. W.; Chang, T. S.; Jeong, W.; Kim, K. Peroxiredoxin, a novel family of peroxidases. IUBMB Life 2001, 52, 35-41.

(35) Luthman, M.; Holmgren, A. Rat liver thioredoxin and thioredoxin reductase: purification and characterization. Biochemistry 1982, 21, 6628-6633.

(36) Rigobello, M. P.; Callegaro, M. T.; Barzon, E.; Benetti, M.; Bindoli, A. Purification of mitochondrial thioredoxin reductase and its involvement in the redox regulation of membrane permeability. Free Radical Biol. Med. 1998, 24, 370-376.

(37) Huber, R. E.; Criddle, R. S. Comparison of the chemical properties of selenocysteine and selenocystine with their sulfur analogs. Arch. Biochem. Biophys. 1967, 122, 
$164-173$.

(38) Johansson, L.; Gafvelin, G.; Arner, E. S. J. Selenocysteine in proteins-properties and biotechnological use. Biochim. Biophys. Acta 2005, 1726, 1-13.

(39) Urig, S.; Becker, K. On the potential of thioredoxin reductase inhibitors for cancer therapy. Semin. Cancer Biol. 2006, 16, 452-465.

(40) Gromer, S.; Urig, S.; Becker, K. The thioredoxin system-from science to clinic. Med. Res. Rev. 2004, 24, 40-89.

(41) Liu, Y.; Li, Y.; Yu, S.; Zhao, G. Recent advances in the development of thioredoxin reductase inhibitors as anticancer agents. Curr. Drug Targets 2012, 13, 1432-1444.

(42) Berners-Price, S. J.; Filipovska, A. Gold compounds as therapeutic agents for human diseases. Metallomics 2011, 3, 863-873.

(43) Bindoli, A.; Rigobello, M. P.; Scutari, G.; Gabbiani, C.; Casini, A.; Messori, L. Thioredoxin reductase: a target for gold compounds acting as potential anticancer drugs. Coord. Chem. Rev. 2009, 253, 1692-1707.

(44) Liu, W. K.; Gust, R. Metal $N$-heterocyclic carbene complexes as potential antitumor metallodrugs. Chem. Soc. Rev. 2013, 42, 755-773.

(45) Cai, W. Q.; Zhang, L. W.; Song, Y. L.; Wang, B. L.; Zhang, B. X.; Cui, X. M.; Hu, G. M.; Liu, Y. P.; Wu, J. C.; Fang, J. G. Small molecule inhibitors of mammalian thioredoxin reductase. Free Radical Biol. Med. 2012, 52, 257-265.

(46) Gan, F. F.; Kaminska, K. K.; Yang, H.; Liew, C. Y.; Leow, P. C.; So, C. L.; Tu, L. N. L.; Roy, A.; Yap, C. W.; Kang, T. S.; Chui, W. K.; Chew, E. H. Identification of Michael acceptor-centric pharmacophores with substituents that yield strong thioredoxin reductase inhibitory character correlated to antiproliferative activity. Antioxid. Redox Signaling 2013, 19, $1149-1165$.

(47) Rice, K. P.; Klinkerch, E. J.; Gerber, S. A.; Schleicher, T. R.; Kraus, T. J.; Buros, C. M. Thioredoxin reductase is inhibited by the carbamoylating activity of the anticancer sulfonylhydrazine drug laromustine. Mol. Cell. Biochem. 2012, 370, 199-207. 
(48) Liu, X.; Pietsch, K. E.; Sturla, S. J. Susceptibility of the antioxidant selenoenyzmes thioredoxin reductase and glutathione peroxidase to alkylation-mediated inhibition by anticancer acylfulvenes. Chem. Res. Toxicol. 2011, 24, 726-736.

(49) Duan, D. Z.; Zhang, B. X.; Yao, J.; Liu, Y. P.; Sun, J. Y.; Ge, C. P.; Peng, S. J.; Fang, J. G. Gambogic acid induces apoptosis in hepatocellular carcinoma SMMC-7721 cells by targeting cytosolic thioredoxin reductase. Free Radical Biol. Med. 2014, 69, 15-25.

(50) Duan, D.; Zhang, B.; Yao, J.; Fang, J. Shikonin targets cytosolic thioredoxin reductase to induce ROS-mediated apoptosis in human promyelocytic leukemia HL-60 cells. Free Radical Biol. Med. 2014, 70, 182-193.

(51) Bindoli, A.; Rigobello, M. P. Principles in redox signaling: from chemistry to functional significance. Antioxid. Redox Signaling 2013, 18, 1557-1593.

(52) Arteel, G. E.; Sies, H. The biochemistry of selenium and the glutathione system. Environ. Toxicol. Pharmacol. 2001, 10, 153-158.

(53) Brigelius-Flohé, R.; Maiorino, M. Glutathione peroxidases. Biochim. Biophys. Acta 2013, 1830, 3289-3303.

(54) Gromer, S.; Arscott, L. D.; Williams, C. H., Jr.; Schirmer, R. H.; Becker, K. Human placenta thioredoxin reductase. Isolation of the selenoenzyme, steady state kinetics, and inhibition by therapeutic gold compounds. J. Biol. Chem. 1998, 273, 20096-20101.

(55) Fan, P. W.; Zhang, F.; Bolton, J. L. 4-Hydroxylated metabolites of the antiestrogens tamoxifen and toremifene are metabolized to unusually stable quinone methides. Chem. Res. Toxicol. 2000, 13, 45- 52.

(56) Fan, P. W.; Bolton, J. L. Bioactivation of tamoxifen to metabolite E quinone methide: reaction with glutathione and DNA. Drug Metab. Dispos. 2001, 29, 891-896.

(57) Hamels, D. Exploration du mecanisme d'action des analogues ferroceniques du tamoxifene. Ph.D. Thesis, Université Pierre et Marie Curie, Paris VI, 2010.

(58) Bersani, N. A.; Merwin, J. R.; Lopez, N. I.; Pearson, G. D.; Merrill, G. F. Protein electrophoretic mobility shift assay to monitor redox state of thioredoxin in cells. Methods 
Enzymol. 2002, 347, 317- 326.

(59) Du, Y.; Zhang, H.; Zhang, X.; Lu, J.; Holmgren, A. Thioredoxin 1 is inactivated due to oxidation induced by peroxiredoxin under oxidative stress and reactivated by the glutaredoxin system. J. Biol. Chem. 2013, 288, 32241-32247.

(60) Rackham, O.; Shearwood, A. M.; Thyer, R.; McNamara, E.; Davies, S. M.; Callus, B. A.; Miranda-Vizuete, A.; Berners-Price, S. J.; Cheng, Q.; Arner, E. S. J.; Filipovska, A. Substrate and inhibitor specificities differ between human cytosolic and mitochondrial thioredoxin reductases: Implications for development of specific inhibitors. Free Radical Biol. Med. 2011, 50, 689-699.

(61) Sun, Q. A.; Wu, Y.; Zappacosta, F.; Jeang, K. T.; Lee, B. J.; Hatfield, D. L.; Gladyshev, V. N. Redox regulation of cell signaling by selenocysteine in mammalian thioredoxin reductases. J. Biol. Chem. 1999, 274, 24522-24530.

(62) Rigobello, M. P.; Vianello, F.; Folda, A.; Roman, C.; Scutari, G.; Bindoli, A. Differential effect of calcium ions on the cytosolic and mitochondrial thioredoxin reductase. Biochem. Biophys. Res. Commun. 2006, 343, 873-878.

(63) Baird, L.; Dinkova-Kostova, A. T. The cytoprotective role of the Keap1-Nrf2 pathway. Arch. Toxicol. 2011, 85, 241-272.

(64) Vessieres, A.; Corbet, C.; Heldt, J. M.; Lories, N.; Jouy, N.; Laios, I.; Leclercq, G.; Jaouen, G.; Toillon, R. A. A ferrocenyl derivative of hydroxytamoxifen elicits an estrogen receptor-independent mechanism of action in breast cancer cell lines. J. Inorg. Biochem. 2010, 104, 503-511.

(65) Lu, C.; Heldt, J. M.; Guille-Collignon, M.; Lemaitre, F.; Jaouen, G.; Vessieres, A.; Amatore, C. Quantitative analyses of ROS and RNS production in breast cancer cell lines incubated with ferrocifens. ChemMedChem 2014, 9, 1286-1293.

(66) Chen, Y.; Yu, M.; Jones, D. P.; Greenamyre, J. T.; Cai, J. Protection against oxidant-induced apoptosis by mitochondrial thioredoxin in SH-SY5Y neuroblastoma cells. Toxicol. Appl. Pharmacol. 2006, 216, 256-262.

(67) Hillard, E.; Vessieres, A.; Le Bideau, F.; Plazuk, D.; Spera, D.; Huche, M.; Jaouen, G. 
A series of unconjugated ferrocenyl phenols: prospects as anticancer agents. ChemMedChem 2006, $1,551-559$.

(68) Top, S.; Vessieres, A.; Cabestaing, C.; Laios, I.; Leclercq, G.; Provot, C.; Jaouen, G. Studies on organometallic selective estrogen receptor modulators. (SERMs) Dual activity in the hydroxy-ferrocifen series. J. Organomet. Chem. 2001, 637, 500-506.

(69) Liu, H.; Liu, J.; van Breemen, R. B.; Thatcher, G. R. J.; Bolton, J. L. Bioactivation of the selective estrogen receptor modulator desmethylated arzoxifene to quinoids: 4'-fluoro substitution prevents quinoid formation. Chem. Res. Toxicol. 2005, 18, 162-173.

(70) Rigobello, M. P.; Bindoli, A. Mitochondrial thioredoxin reductase purification, inhibitor studies, and role in cell signaling. Methods Enzymol. 2010, 474, 109-122.

(71) Flohé, L.; Gunzler, W. A. Assays of glutathione peroxidase. Methods Enzymol. 1984, $105,114-121$.

(72) Fang, J.; Lu, J.; Holmgren, A. Thioredoxin reductase is irreversibly modified by curcumin: a novel molecular mechanism for its anticancer activity. J. Biol. Chem. 2005, 280, 25284-25290.

(73) Prast-Nielsen, S.; Cebula, M.; Pader, I.; Arner, E. S. J. Noble metal targeting of thioredoxin reductase-covalent complexes with thioredoxin and thioredoxin-related protein of 14 kDa triggered by cisplatin. Free Radical Biol.Med. 2010,49, 1765-1778.

(74) Tietze, F. Enzymic method for quantitative determination of nanogram amounts of total and oxidized glutathione: applications to mammalian blood and other tissues. Anal. Biochem. 1969, 27, 502-522.

(75) Anderson, M. E. Determination of glutathione and glutathione disulfide in biological samples. Methods Enzymol. 1985, 113, 548-555.

(76) Lowry, O. H.; Rosebrough, N. J.; Farr, A. L.; Randall, R. J. Protein measurement with the Folin phenol reagent. J. Biol. Chem. 1951, 193, 265-275.

(77) Du, Y.; Zhang, H.; Lu, J.; Holmgren, A. Glutathione and glutaredoxin act as a backup of human thioredoxin reductase 1 to reduce thioredoxin 1 preventing cell death by 
aurothioglucose. J. Biol. Chem. 2012, 287, 38210-38219. 